\title{
Impact of urban conditions on firm performance of migrant entrepreneurs: a comparative Dutch-US study
}

\author{
Mediha Sahin • Peter Nijkamp • Roger Stough
}

Received: 4 March 2009 / Accepted: 9 September 2009 / Published online: 5 January 2010

(C) The Author(s) 2010. This article is published with open access at Springerlink.com

\begin{abstract}
Recent studies on ethnic entrepreneurship have pointed at an increasing share of migrants in urban small- and medium-sized entrepreneurial businesses. These migrant activities are crucial to the urban economy in many countries, as they employ a significant part of the workforce. The main objective of our study is to identify success conditions of ethnic entrepreneurship by using concepts from social capital and human capital from the literature on empirical factors that are responsible for successful ethnic entrepreneurship. The empirical part of the paper is based on a survey questionnaire among migrant entrepreneurs in the city of Amsterdam in the Netherlands and in Fairfax, County in the state of Virginia in the US. We present an overview of cultural, ethno-psychological and motivational aspects that contribute to the understanding of similarities and differences between ethnic entrepreneurs in both locations. The analysis is structured around several dimensions of social and human capital including personal and business characteristics, and network participation for improving business performance. The findings of the two studies are compared to explore a possible correspondence in business performance patterns. The research tool used to assess performance is Data Envelopment Analysis (DEA), a technique for comparative efficiency analysis in various types of corporate organizations. Finally, concluding remarks are presented and possible extensions of the analysis are suggested.
\end{abstract}

\footnotetext{
M. Sahin $(\bowtie) \cdot$ P. Nijkamp

Department of Spatial Economics, VU University, Amsterdam, The Netherlands

e-mail: msahin@feweb.vu.nl

P. Nijkamp

e-mail: pnijkamp@feweb.vu.nl

R. Stough

School of Public Policy, George Mason University, Fairfax, VA, USA

e-mail: rstough@gmu.edu
} 


\section{JEL Classification $\quad \mathrm{L} 26 \cdot \mathrm{R} 11$}

\section{Entrepreneurial regions in motion}

The past decades have shown a remarkable growth in entrepreneurship among migrants. Ethnic entrepreneurship has increasingly become an important feature of business life in urban areas. There are various studies on ethnic entrepreneurship that have identified both failure and success conditions for an ethnic entrepreneur (BaycanLevent et al. 2003; CEEDR 2000; Choenni 1997; Delft et al. 2000; Greenwood 1994; Masurel et al. 2002; Min 1987; Nijkamp 2003; Sahin et al. 2006; Waldinger et al. 1990; Ward and Jenkins 1984). Various conceptual perspectives have been adopted to study ethnic entrepreneurship (Menzies et al. 2006), and recent studies appear to focus attention in particular on social, human and financial capital theory. For example, Butler and Greene (1997) highlight the importance of a community dimension inherent in the business creation process and the significant contributions of community resources to the entrepreneurial performance of group members.

Creativeness, risk-taking behaviour, courage, technological and market knowledge as well as human and social capital and skills are usually regarded as important driving forces of successful entrepreneurship. Education, capital start-up, previous experience, and parental occupation (class resources) have been found to be more important in business success than ethnic involvement (Marger 1989), while highly successful entrepreneurs have been found to make less use of social capital (Shin and Han 1990). Others have analysed the relative contribution of immigrants to entrepreneurial activity in their host country (Light and Rosenstein 1995; Kim et al. 2003; Hammarstedt 2001; Levie and Smallbone 2006). The general finding is that in many countries migrants are known to make a disproportionately quantitative contribution to new business activities (Keeble 1989; Keeble and Tyler 1995; Kalantardis and Bika 2006; Levie 2007). This paper is concerned with the performance conditions of ethnic (or migrant) entrepreneurship based on social and human capital assets. Its performance and successes are often ascribed to specific characteristics of migrant entrepreneurs (e.g., socio-cultural networks, community sense).

It is increasingly recognized that the wealth and progress of multicultural urban regions is not only influenced by an efficient usage of traditional production factors, but also - and in particular-by social and human factors (Putnam 2000). This has prompted in recent years much research on both social capital (e.g., economic synergy through open multi-actor networks, cooperative modes of initiatives among stakeholders and business actors) and human capital (e.g., motivational incentives, leadership style, locus of control). Our paper addresses in particular the latter two categories as critical success factors for enhanced business performance in multicultural entrepreneurial regions, especially urban areas.

Ethnic entrepreneurship research studies are generally based on case studies, surveys with small samples, or utilize secondary databases. Obtaining respondent cooperation is particularly difficult as many ethnic groups members, especially visible minorities, may belong to the 'grey sector' and be less inclined to participate in survey research. While there is a growing literature on different aspects of ethnic 
entrepreneurship (Levie and Smallbone 2006; Levie 2007), far less research has been conducted on the comparison of the performance of businesses started by migrant entrepreneurs in the EU and the USA. We first offer an overview of some basics from the literature on social and human capital. Then we position these concepts in a general framework on modern regional/urban development, in which changing labour market conditions (with a multicultural dimension) and new entrepreneurship conditions (in particular, the emergence of urban/regional migrant entrepreneurship) play an important role.

\section{Theoretical framework: social and human capital assets}

Regional development is the outcome of socio-economic processes and decisions, in particular the intelligent combination of various production factors and local resources which are decisive for the productivity-enhancing potential of the business sector. The search for appropriate explanatory frameworks for strong business performance has uncovered in recent years an increasing interest in the contribution of 'social capital' to urban or regional development. Social capital was defined by Bourdieu (1986) as follows: "Social capital is an attribute of an individual in a social context". One can acquire social capital though purposeful actions and can transform social capital into conventional economic gains. The ability to do so, however, depends on the nature of the social obligations, connections, and networks available to you" (p. 243). Social capital can assume different forms such as social skills, charisma, cooperative nature or care for others which may create various benefits for the individual or his/her social environment. They are essentially a form of social externalities with positive revenues for most if not all actors involved (see Glaeser et al. 2000; Sobel 2002). Social capital is thus a productive resource at the interface of individual and collective interests (see Dasgupta and Serageldin 1999; Putnam 2000), and serves as an intangible (often hidden) source of well-being in an individualistic modern society.

Social capital is essentially based on the notion of community trust (see Fukuyama 1995) as introduced in the urban planning literature several decades ago by Jane Jacobs (1961). But it has emerged recently in a new form as a productive factor that may stimulate regional (or urban) development. Research from this perspective by Westlund and Bolton (2003) and Westlund and Nilsson (2005) concludes that social capital has several manifestations as

- Capital in an economic sense (with a productivity-enhancing potential, with a blend of supporting factors, with accumulation and deprecation features, with a mix of private and public goods characteristics, and with various spatial and group levels);

- A generator of producer surplus (with a quality-generating potential, with an areaspecific social benefit and with a decline in transaction costs); and,

- A facilitator of entrepreneurship (with a combination of skills, risk-taking attitude, market insights, and goodwill trust).

There is convincing evidence that social capital plays a prominent role in a networked society, where reliability, trust, standardization and efficient inter-actor operations are the keys to success and competitive performance (Sobel 2002). Socio-economic interaction in networks and confidence and trust among network actors are closely related 
phenomena (see also Dyer and Ross 2000). In addition, during recent decades, considerable attention has been paid to the relationship between self-employment and social capital. Family based social capital in the form of mutual obligation and trust encourages highly motivated and cooperative group efforts in the pursuit of common objectives (see Sanders and Nee 1996). There has been a rapidly rising volume of studies on social capital and trust, from the side of both economists and sociologists (see also Chou 2006). Unfortunately, the number of applied studies where trust and social capital are operationalized is disappointingly low. There is clearly a much needed scope for original empirical research on social capital, in particular in the context of regional development where local resources such as social capital appear to play a highly prominent role. Empirical research on the significance of social capital is once more warranted, as differences in social capital among regions may contribute to widening spatial disparities. Furthermore, social capital is often defined in terms of trust, information flows, and norms between individuals, both inside and outside a business and has been categorized into structural, relational and cognitive dimensions (see Nahapiet and Ghoshal 1998; De Carolis and Saparito 2006). Social capital factors that have been found or proposed to affect new venture performance (both positively and negatively) include interaction with local (see Mueller 2005; Bates 1999) and foreign business networks (Prashantham 2006). According to Fratoe (1988) and Holguin et al. (2006), social capital can be defined as the network of business associates, family members, customers and employees that can be highly important in starting a business and the development of new business. In the context of our study on migrant entrepreneurs, we may interpret social capital as the set of facilitating network factors that include the use of co-ethnic markets, co-ethnic suppliers and employees, community sources of capital, advice and information, as well as membership in ethnic community organizations. The literature claims that the benefits derived from belonging to a particular ethnic group and the use of the associated networks greatly enhance the start-up and continuing business success of an ethnic business (Adler and Kwon 2002; Menzies et al. 2003; Dyer and Ross 2000; Boubakri 1999; Iyer and Shapiro 1999; Werbner 1999; Dhaliwal 1998; Teixeira 1998; Deakins et al. 1997; Ram 1994; Peterson and Roquebert 1993; Waldinger 1988; Aldrich and Zimmer 1986; Light 1984; Bonacich et al. 1976). It is noteworthy that social capital also contributes to human capital. Human capital includes education, experience, the influence of one's family influence and age (Becker 1975; Oort and Atzema 2004).

The literature offers ample evidence of the importance of human capital in the pursuit of self-employment (Sanders and Nee 1996). According to Sanders and Nee (1996) human capital refers to possession of skills, work experience, knowledge and other useful characteristics (e.g., motivational incentives, leadership style, locus of control) that facilitate self-employment. Human capital factors that in recent studies have been found to affect new venture performance include age, gender, ethnicity (Cooper et al. 1994), education (Shepherd et al. 2000; Lee and Lee 2004; Lee and Chang 2005), relevant industry experience (Baum et al. 2001; Kakati 2003; Florin et al. 2003; Lee and Chang 2005) and general management experience (Brown and Hanlon 2004). Human capital such as education and language proficiency enables immigrants to effectively deal with a range of challenges. Some scholars have claimed that the success of entrepreneurs can be attributed to their superior human capital rather than to 
business ownership (Sanders and Nee 1996; Borjas 1990). Bates (1994a,b) has shown that human capital resources are positively related to business longevity and profits. Ethnic entrepreneurs with a higher educational qualification appear to have greater chances for success (Basu 1998; Bates 1994a,b; Birley and Ghaie 1992). Anderson and Miller (2003) found that human and social capital assets of an entrepreneur had a major influence on the choice of industry and type of new business as well as its future potential for profitability. The most important indicators of the extent of the human and social capital assets of an entrepreneur were related to the socio-economic position into which the entrepreneur was born. Relatively low levels of human capital may limit the ability of migrant entrepreneurs to successfully run their businesses, and restricted access to financial capital may result in undercapitalized business. In the remainder of this paper, we investigate the critical success conditions (and failure conditions) that are decisive for the economic performance of migrant entrepreneurs in the service sector in two urban regions, viz. the Greater Amsterdam Area (the Netherlands) and Fairfax County (Virginia). ${ }^{1}$ Before we embark on the database employed in our study (Sect. 4), we offer a sketch of migrant entrepreneurship in both the Netherlands and the USA (Sect. 3).

\section{Immigrants and entrepreneurship: Dutch and US evidence}

Entrepreneurship is crucial to economic growth and urban regional development (Acs and Audretsch 1993; Acs and Armington 2006; Yu and Stough 2006): entrepreneurship contributes to competitiveness, new jobs, economic growth and social cohesion. There is an abundance of literature on entrepreneurship (see for recent surveys by Audretsch and Thurik 2001; Hébert and Link 1989; Lumpkin and Dess 1996, and Wennekers and Thurik 1999). Many migrants appear to possess a strong potential and capacity for entrepreneurship, and they show particular dynamism in creating enterprises. They are even more likely to be self-employed than natives. For example, in the US, migrants are over-represented among self-employed workers (Tanaka and Krishnan 2006).

The most prominent advantage of ethnic entrepreneurship is its contribution to reducing social exclusion and raising living standards in groups that can often be among the most disadvantaged in society. Migrant entrepreneurs contribute to a more diversified range of products supplied, raising competition and indirectly the quality of products. Furthermore, the benefits of ethnic entrepreneurship consist of social bonds in a cultural network, which create flexible ways to attract personal and capital and the capacity of generate market niches for specific cultural goods (e.g., music and food). In countries like the Netherlands and the US, migrant entrepreneurship has proven to be an efficient means of socio-economic integration contributing significantly to the overall economic growth and development of the area concerned. Ethnic entrepreneurship has a social as well as an economic impact on a society's

\footnotetext{
1 The population size of the Greater Amsterdam Area is well above one million, while this area is part of the Dutch Randstad with some 5 to 6 million people. Fairfax County has a population in excess of one million and is part of the U.S. National Capital Region which is a market of about 5 million people.
} 
Table 1 Number of entrepreneurs (x1,000), 1999-2004 (CBS, 2007)

\begin{tabular}{cclll}
\hline Year & Turks & Moroccans & Netherlands/Antilles & Surinamese \\
\hline 1999 & 7.9 & 2.8 & 1.5 & 6.4 \\
2000 & 9.2 & 3.3 & 1.8 & 7.1 \\
2001 & 11.0 & 4.0 & 2.0 & 7.8 \\
2002 & 11.5 & 4.3 & 2.1 & 7.9 \\
2003 & 11.9 & 4.4 & 2.2 & 8.0 \\
2004 & 11.8 & 4.6 & 2.1 & 7.7 \\
\hline
\end{tabular}

development in both short-term and long-term perspectives (Teder and Golik 2006). Exploring ethnic entrepreneurs is thus highly important, for both social and economic reasons.

\subsection{Entrepreneurial migrants in the Netherlands}

The Netherlands has a migrant population of over $2,800,000$ or $17.4 \%$ of the total population). Of these, $51.9 \%$ is composed of first-generation migrants, while $40 \%$ of the migrants live in the four largest cities (Tillie and Slijper 2006). The influx of migrants and the selective outflow of natives have induced fast changes in ethnic composition of the four largest Dutch cities, where Surinamese, Antilleans, Turks and Moroccans are the largest migrant minority groups.

The socio-economic characteristics of migrants living in the Netherlands can be summarized as follows: migrants are younger than natives; the proportion of males is higher in the migrant population; migrants are concentrated in four large cities (Rotterdam, Amsterdam, The Hague and Utrecht); the skill levels of migrants are below that of the native population, and their occupational status is below that of natives with comparable skill levels. Finally, migrants have higher rates of unemployment (Brücker et al. 2002).

Since the late 1980s, the number of migrant entrepreneurs has increasingly risen in the Netherlands. The number of non-Western entrepreneurs increased from 34,100 in 1999 to 46,900 in 2004, with an average annual increase of 3.8\%. In 2004, after years of economic recession, the labour market participation among immigrants was only $48 \%$, while the unemployment rate among immigrants was $16 \%$, three times higher compared to the native Dutch population (Zorlu and Traag 2005). This has prompted an increasing number of immigrants to become self-employed.

It is noteworthy that among Western immigrants the number of entrepreneurs increased from 72,700 to 74,500 ( $0.2 \%$ annually), whereas among native Dutch the number of entrepreneurs decreased from 819,000 in 1999 to 818,300 in 2004. Thus, among non-Western immigrants, there is an increasing trend to become entrepreneurs, while there is a decreasing trend to becoming an entrepreneur among Western immigrants and native Dutch. In absolute numbers, the Turks and Surinamese are the largest group of migrant entrepreneurs in the Netherlands (Table 1). However, in the period 1999-2004 the sharpest increase was among Moroccan entrepreneurs, namely $64 \%$. 
Table 2 Sectoral distribution among non-Western immigrant entrepreneurs, 2004 (in percentages) (Dagevos and Gesthuizen 2005)

\begin{tabular}{lcccc}
\hline & Turks & Moroccans & Surinamese & Antilleans \\
\hline Agriculture/fishing & 4 & 2 & 0 & 1 \\
Industry & 5 & 2 & 3 & 3 \\
Building industry & 7 & 6 & 6 & 12 \\
Trade and reparation business & 6 & 6 & 3 & 2 \\
Wholesale & 9 & 7 & 11 & 10 \\
Retail trade & 19 & 26 & 15 & 11 \\
Hotel and catering industry & 20 & 17 & 9 & 6 \\
Transportation, storage and communication & 6 & 8 & 6 & 3 \\
Financial institutions & 1 & 0 & 2 & 1 \\
Real estate & 1 & 1 & 3 & 1 \\
Producer services/business to business & 16 & 14 & 24 & 30 \\
Other services & 6 & 11 & 18 & 19 \\
\hline
\end{tabular}

There are considerable differences in the self-employment rates among the different ethnic groups in the Netherlands. Although the hotel and catering sector is still most popular among the older immigrants (first generation), the percentage has declined considerably. Instead, the new generation chooses more often to become active in the business (or producer) services sector which includes finance, insurance, real estate and business-related professional services, such as accounting, consulting, marketing, engineering, or design, most of which employ a high share of technical, professional and managerial jobs. The younger group of immigrants (second generation) is predominantly represented in the producer services sector. In 2002, one quarter of this group started its business in this sector. As a result, the sectoral distribution of the younger generation of migrant entrepreneurs has become more similar to the composition of the native Dutch entrepreneurs. According to the study of Dagevos and Gesthuizen (2005), Surinamese and Antillean entrepreneurs are more often active in the producer services than other ethnic groups (Table 2). Among Turkish entrepreneurs there is a more than average increase of entrepreneurs in the producer services as well.

\subsection{Entrepreneurial migrants in the United States}

Self-employment continues to be an important source of jobs in the United States (US) (Hipple 2004). Small- and medium-sized entrepreneurial businesses are vital to the US economy, as they employ more than half of the private sector workforce. Recent decades have experienced a large growth in entrepreneurship among migrants in the US. They have shown higher rates of entrepreneurship compared with the US born population (Torres 1988; Light 1984). In 1997, there were 615,200 minority-owned businesses in the US that, generated $87.4 \%$ of the total minority-owned business revenue of $\$ 591.3$ billion. There were 1,199,900 Hispanic-owned businesses; 823,500 
Table 3 Firms by race and ethnic origin

\begin{tabular}{lcc}
\hline & Number of firms & Percentage of firms \\
\hline Total US firms & $20,821,934$ & 100 \\
Non-minority firms & $17,782,901$ & 85.40 \\
All Minority firms & $3,039,033$ & 14.60 \\
Black-owned & 823,499 & 3.96 \\
Hispanic-owned & $1,199,896$ & 5.76 \\
American Native-owned & 197,300 & 0.94 \\
Asian-owned & 912,959 & 4.38 \\
\hline
\end{tabular}

The percentages may not sum to 100 , because Hispanics may be of any race and may therefore be double counted

Source US Department of Commerce, Bureau of the Census, SMBO, 1997

Black-owned businesses; 913,000 Asian-owned businesses; and 197,300 Native American-owned businesses in 1997. In the State of Virginia, self-employment increased by $12.4 \%$, from 186,884 in 2002 to 210,013 in 2003 . In 1997 , there were 14,300 minority-owned businesses, and they generated $87.4 \%$ of the total minorityowned business revenue of $\$ 10.2$ billion in Virginia. There were 13,700 Hispanicowned businesses; 33,500 Black-owned businesses; 22,400 Asian-owned businesses; and 3,300 Native American-owned businesses (Richtmyer 2002). In short, these data suggest the disproportionately large participation in business development on the part of minority and ethnic groups of which a significant part are immigrants.

Table 3 shows that migrants own about $15 \%$ of total firms in the US, with Hispanics, Asians, Blacks and American Natives owning 6\% or less of the firms (Richtmyer 2002).

Table 4 shows the percentage of minority-owned businesses by major industry. The Asian-owned firms are strongly represented in the services and retail industries. Hispanic-owned firms are concentrated in construction, retail, services and unclassified sectors. Blacked-owned firms are very similar to all firms, while native Americanowned businesses are strongly represented in the unclassified, services and construction industries.

Table 5 shows the number of firms for the period 1982-1997. During this period minority-owned firms grew at a rate of 55\% compared to nonminority-owned firms' rate of 11\%; in 1987-1992, minority-owned firms showed a 68\% growth rate compared to a growth rate of non-minority-owned firms of 22\%; and in 1992-1997, minorityowned firms continued to grow at a rate of $30 \%$ compared to nonminority-owned firms' rate of $4 \%$. In sum, minority-owned firms grew at much higher rates than majority-owned firms.

There are great variations in the self-employment rates of different immigrant and ethnic groups in the US. Research does not support a consensus in arguments for this variation, with some proposing that immigrant communities are themselves differential sources of entrepreneurial energy and others suggesting that it is the result of the human and/or financial capital of individual immigrants. Ethnic differences among entrepreneurs' motivations can vary from one location to another, and depend on 
Table 4 Percentage of minority-owned firms by industry, 1997

\begin{tabular}{lccccc}
\hline Major industry & Total (\%) & Black $(\%)$ & Hispanic (\%) & American native (\%) & Asian (\%) \\
\hline All & & 3.95 & 5.76 & 0.95 & 4.38 \\
\hline Agriculture & 2.38 & 1.51 & 3.34 & 4.53 & 1.42 \\
Mining & 0.61 & 0.03 & 0.16 & 0.48 & 0.07 \\
Construction & 11.21 & 6.86 & 12.72 & 13.91 & 3.04 \\
Manufacturing & 3.31 & 1.27 & 2.13 & 3.40 & 2.55 \\
Transportation & 4.42 & 8.69 & 7.05 & 3.19 & 4.11 \\
Wholesale & 3.83 & 0.99 & 2.62 & 2.21 & 5.52 \\
Retail & 13.87 & 10.63 & 12.92 & 7.49 & 21.43 \\
Finance & 10.75 & 4.61 & 4.72 & 2.34 & 4.53 \\
Services & 42.70 & 53.14 & 41.71 & 17.31 & 9.91 \\
Unclassified & 7.11 & 12.28 & 12.66 & 45.23 &
\end{tabular}

A large number of unclassified businesses within the Native American group may be gambling businesses (Minorities in Business, 2001)

Source Table derived from Richtmyer (2002)

Table 5 Growth in numbers of minority-owned firms (1982-1997)

\begin{tabular}{|c|c|c|c|c|c|c|c|}
\hline & \multicolumn{4}{|c|}{ Number of firms } & \multicolumn{3}{|c|}{ Growth rates $(\%)$} \\
\hline & 1982 & 1987 & 1992 & 1997 & '82-‘87 & '87-'92 & '92-97 \\
\hline All US firms & $12,059,950$ & $13,695,480$ & $17,253,143$ & $18,431,456$ & 14 & 26 & 7 \\
\hline Nonminority firms & $11,234,999$ & $12,419,170$ & $15,103,959$ & $15,645,358$ & 11 & 22 & 4 \\
\hline All Minority firms & 824,951 & $1,343,910$ & $2,149,184$ & $2,786,098$ & 55 & 68 & 30 \\
\hline Black-owned & 308,260 & 424,165 & 620,912 & 780,770 & 38 & 46 & 26 \\
\hline Hispanic-owned & 28,401 & 489,973 & 862,605 & $1,121,433$ & 73 & 76 & 30 \\
\hline $\begin{array}{l}\text { American } \\
\text { Native- } \\
\text { owned }\end{array}$ & 17,100 & 24,931 & 102,271 & 187,921 & 46 & 310 & 84 \\
\hline Asian-owned & 240,806 & 414,340 & 603,426 & 785,480 & 72 & 46 & 30 \\
\hline
\end{tabular}

Source Table derived from Richtmyer (2002) U.S. Small Business Administration, Office of Advocacy, based on data from the U.S. Department of Commerce, Bureau of the Census, Survey of Minority-Owned Business Enterprises, Company Statistics Series 1982, 1987, 1992, and 1997

social class differences, opportunity structures and ethnic group relations in a particular location. Statistical analyses conducted by Yuengert (1995) suggest that $62 \%$ of the immigrant self-employment business participation rates in the US may be explained by two rather more sophisticated features of immigrant communities. Immigrants from countries with high self-employment rates have higher than average self-employment rates in the U.S., perhaps because they are more likely to be experienced business people. Also, immigrants tend to concentrate in states with progressive tax and regulatory codes, which may act as incentives to pursue self-employment, with its greater opportunities for tax avoidance (Aronson 1997). 
Several scholars claim that migrants are more likely to express a desire and to try starting a business than natives, but are also more likely to fail (Köllinger and Minniti 2006). Studies in the US show that migrant entrepreneurs tend to have less personal funds available at start-up and are less likely to seek funding from formal sources than non-minority entrepreneurs. Studies on migrant entrepreneurship in the US rank the groups by the percentage of owners, by estimated employees, or by ethnic traits (Koreans, Asians, Indians, Japanese, Cuban, Chinese, Vietnamese, Filipino, Mexican, Puerto Rican, African Americans and Hawaiian; see Light and Gold 2000). According to Portes and Zhou (1996) and Light and Roach (1996), self-employed Cuban, Chinese, and Japanse and Korean entrepreneurs received higher incomes than their salaried co-ethnics in the general market. According to Bates (1994a), the high level of success of Koreans in the US vis-à-vis others is due to their educational levels and personal wealth or access to resources.

Robb and Fairlie (2007) found that Asians are the most educated racial group in the US. Other findings were that related to family business background of the owner, marriage is associated with business success. Spouses may provide financial assistance, paid or unpaid labour for the business, health insurance coverage, and other types of assistance useful for running a business (Robb and Fairlie 2007). They also argue that financial and human capital contribute to the relative success of Asian businesses. According to these scholars, Asian-owned businesses are more successful than whiteowned businesses for two main reasons; Asian owners have high levels of human capital and their businesses have substantial start up capital. Bates (1994a) argues that Vietnamese business owners rely on co-ethnic customers and employees, but Asian business owners in general rely less on their co-ethnic group.

In the United States, migrants from India tend to dominate in the low-budget hotel business, Koreans specialize in retail businesses and Chinese run restaurants. Often, migrant entrepreneurs take over businesses that natives are leaving. In the United States an increasing number of farms are owned by Hispanic and Asian migrants, at a time when many older, native-born farmers are leaving farming altogether (Aronson 1997).

Bates (1994a) comparative studies of Korean immigrant-owned businesses with African-American and non-minority owned businesses suggest that human and financial capital — and not social capital alone — are the key determinants of business activity. Korean entrepreneurs are more likely to have college degrees and more likely to have invested substantial personal assets in their businesses; their financial returns, however, tend to be significantly below those of African-American entrepreneurs, suggesting that the Koreans turned to self-employment because they faced barriers entering the labor market (Aronson 1997). Access to capital, networking, training and support services are challenges that immigrant entrepreneurs often face. Immigrants need literacy and job-training programs. All immigrant entrepreneurs with limited English proficiency bring home lower earnings than those with greater proficiency.

As a final caveat, it has to be recognized that ethnic entrepreneurship in the Netherlands and the US is showing strong growth, but self-employment rates in both countries differ across ethnic groups. We will describe the methodology for our empirical research and the empirical data base used to identify the importance of social and human capital factors in the next part of the paper. 


\section{Methodology: research design and database}

Our study aims primarily to investigate the similarities and differences between ethnic entrepreneurs in the Greater Amsterdam Area (the Netherlands) and in Fairfax County (Virginia, US), in terms human and social capital described above. Figure 1 shows an analysis framework for empirical research that maps out how the social and human capital elements are related to entrepreneurship and entrepreneurial performance.

We will now empirically test the explanatory profile composed of three main constructs: social capital (e.g., network participation, other relatives as entrepreneur), human capital (personal and business characteristics) and business performance. To that end, we conducted a questionnaire for ethnic entrepreneurs in both Amsterdam and Fairfax. The questionnaires contain personal-information questions (e.g., demographic and socio-economic data), but also questions pertaining to-motivation, business performance, socio-cultural network participation, financial and market and evaluation questions. From the full set of questions, we have selected those which may be interpreted as indicators for the input factors of the production system of each migrant entrepreneur, as well as questions which may be seen as typical for the performance of the firm concerned (see also Sahin et al. 2007). The following input and output indicators were selected (see Table 6).

The independent variable personal characteristics, is constructed from items concerning the need for achievement, locus of control and risk-taking propensity. This variable consists of 15 items taken primarily from the E-Scan of Driessen and Zwart (2006). The E-Scan is a test for potential entrepreneurs to see if they have the appropriate characteristics to be an entrepreneur. These are used in this study because they are the most frequently investigated and cited characteristics of the entrepreneur found in the literature, and they show a significant relationship with entrepreneurship across several studies (Carland and Carland 1993; Hansemark 1998; Johnson 1990). The independent variable business characteristic is constructed from 11 items about business experience, plant experience, innovation, total number of people working in the enterprise, funding and items about business strategy. The two clusters of the

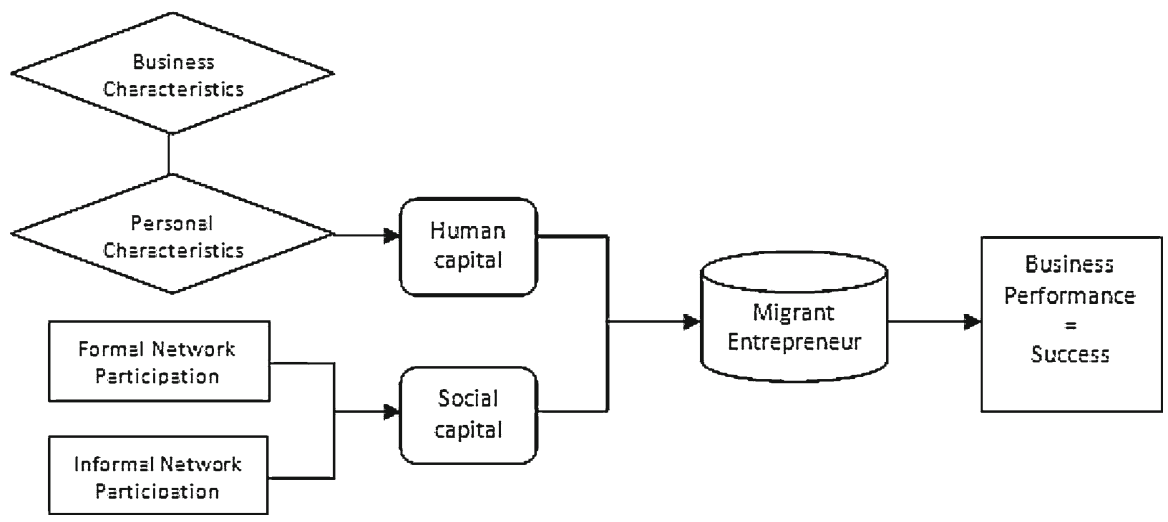

Fig. 1 Entrepreneurial performance as a result of human and social capital 
Table 6 Input and output indicators of migrant entrepreneurs

\begin{tabular}{|c|c|c|c|c|c|c|c|}
\hline \multicolumn{8}{|l|}{ Indicators } \\
\hline \multicolumn{5}{|l|}{ Input } & \multicolumn{3}{|l|}{ Output } \\
\hline $\mathrm{PC}$ & SE & IS & ES & LS & MS & GT & PT \\
\hline \multirow[t]{2}{*}{$\begin{array}{l}\text { Need for a } \\
\text { achievement }\end{array}$} & $\begin{array}{l}\text { Number of } \\
\text { full-time } \\
\text { employees }\end{array}$ & Commitment & $\begin{array}{l}\text { Applicable } \\
\text { products } \\
\text { and } \\
\text { services }\end{array}$ & $\begin{array}{l}\text { Negotia- } \\
\text { tion skills }\end{array}$ & $\begin{array}{l}\text { MARKET } \\
\text { SHARE }\end{array}$ & $\begin{array}{l}\text { GROWTH } \\
\text { IN TURN- } \\
\text { OVER }\end{array}$ & PROFIT \\
\hline & & $\begin{array}{l}\text { Culture of } \\
\text { enterprise }\end{array}$ & & $\begin{array}{l}\text { Commu- } \\
\text { nication } \\
\text { skills }\end{array}$ & & & \\
\hline \multirow[t]{6}{*}{$\begin{array}{l}\text { Locus of } \\
\text { control }\end{array}$} & $\begin{array}{l}\text { Number of } \\
\text { part-time } \\
\text { employees }\end{array}$ & Administration & $\begin{array}{l}\text { Availabil- } \\
\text { ity of } \\
\text { finance }\end{array}$ & $\begin{array}{l}\text { Manage- } \\
\text { rial skills }\end{array}$ & & & \\
\hline & & Reliability & & & & & \\
\hline & & $\begin{array}{l}\text { Market } \\
\text { knowledge }\end{array}$ & $\begin{array}{l}\text { Expecta- } \\
\text { tions of } \\
\text { market }\end{array}$ & $\begin{array}{l}\text { Customer } \\
\text { relation- } \\
\text { ships }\end{array}$ & & & \\
\hline & & $\begin{array}{l}\text { Customer } \\
\text { service }\end{array}$ & & & & & \\
\hline & & Personnel & Innovation & $\begin{array}{l}\text { Financial } \\
\text { knowledge }\end{array}$ & & & \\
\hline & & Quality & & & & & \\
\hline \multicolumn{4}{|l|}{$\begin{array}{l}\text { Risk- } \\
\text { taking } \\
\text { propensity } \\
\text { Input factors }\end{array}$} & $\begin{array}{l}\text { Market } \\
\text { orientation } \\
\text { Output facto }\end{array}$ & rs & & \\
\hline \multicolumn{4}{|c|}{$\mathrm{PC}=$ Personal characteristics (motivation factor) } & $\mathrm{MS}=$ Marke & et share & & \\
\hline \multicolumn{4}{|c|}{$\mathrm{SE}=$ Size of enterprise } & \multicolumn{4}{|c|}{$\mathrm{GT}=$ Growth in turnover } \\
\hline \multicolumn{4}{|c|}{ IS $=$ Internal success } & $\mathrm{PT}=$ Profit & & & \\
\hline \multicolumn{8}{|c|}{$\mathrm{ES}=$ External success } \\
\hline \multicolumn{8}{|c|}{$\mathrm{LS}=$ Learned skills } \\
\hline
\end{tabular}

aforementioned items are altogether recomputed to one variable using principal components analysis, each using the Statistical Package for the Social Sciences (SPSS). During the creation of the main constructs, we performed a reliability analysis to investigate if we could use the constructs for further analysis. We measured these items with Cronbach's alpha and used a critical value of 0.6 or higher (Velde et al. 2000). The values for Cronbach's alpha for both items were sufficient to use in further research on the influence of migrant entrepreneurs on business performance.

In the literature business performance is often divided into objective and subjective components of business performance. In our study, business performance refers to the objective criteria: market share, turnover and profitability (e.g., net and gross profit). Besides these variables, we also included internal and external success factors, or attributes, such as productivity, costs, stability, growth, business culture, reliability, market knowledge, employees, quality, price, innovation, products, etc. in order to measure the business performance of migrant entrepreneurs. Each attribute is linked 
to five questions, whereby the respondent answered on a 5-point Likert scale: 'strongly disagree', 'disagree', 'neither agree or disagree', 'agree', 'strongly agree'. Based on their answers, the respondent can score points varying between 5, 4, 3, 2, and 1. Some statements are reverse-scored to minimize response-set bias and the halo-effect. It is noteworthy that some researchers have reported a high internal reliability for these measures (Ho and Koh 1992). For each of the three traits, once all scale scores have been reflected to ensure appropriate alignment for the analysis, a higher score indicates a greater need for achievement, more locus of control and higher risk-taking propensity. Five points is the highest score per answer, while one point is the lowest per question. The average of the scores is used for each of the variables and constructs. The averages are used in the subsequent analyses to investigate differences between migrant groups (see Table 7).

The sampling was restricted to those enterprises that are owned by migrant entrepreneurs of different ethnic origin in the service sector (e.g., consultancy, accountancy, and tax offices), and the retail sector (e.g., restaurants, beauty salons, etc.). The total sample included 83 respondents of Turkish, Moroccan and Surinamese origin in the service sector in Amsterdam, and 42 respondents of Korean, Vietnamese and other origin in the service and retail sectors in Fairfax. The population was confined to three migrant groups of people in the Netherlands who are originally from Turkey, Morocco and Surinam, and to those migrant groups in the US who are originally from Korea, Vietnam and other countries, because of their size and numbers in the selected sectors. Our research used survey questionnaires handed out to the respondents. The research questionnaire included open-ended and closed questions to collect the necessary information. The respondents are segmented in our research according to their ethnic origin, viz. Turkish, Moroccan, and Surinamese, Korean, Vietnamese, or different origin. Their ethnic origin is confirmed by the country of birth of the parents, as well as by the individual respondent. The approach was based on personally supervised assistance in obtaining the various questions and, hence, once an entrepreneur had agreed to participate in this exercise, he/she was normally willing to complete the questionnaire.

\subsection{Database on migrant entrepreneurs in the service sector in the Amsterdam area}

Tables 8 and 9 show personal and entrepreneurial characteristics of the relevant group in Amsterdam. In Table 8 we present an overview of the profile of the 83 respondents in the service sector in Amsterdam and the Pearson Chi-Square ( $p$ value) of the statistical difference among the groups.

Most of the entrepreneurs were aged between 26 and 30 years (29\%) (Table 8). However, this was different for each migrant group. Most entrepreneurs of Turkish origin were between the age of 30-35 (11\%), while most of the entrepreneurs of Moroccan origin were between the age of 25-30 (16\%), and most of the Surinamese entrepreneurs were between the age of 35-39 (8\%). We find a statistical outcome of 0.04 for the Pearson Chi-Square value (see Table 10), so that we may conclude that the entrepreneurs from the three ethnic groups considered do differ significantly from each other regarding their age. From this table, we can also derive that the entrepreneurs 


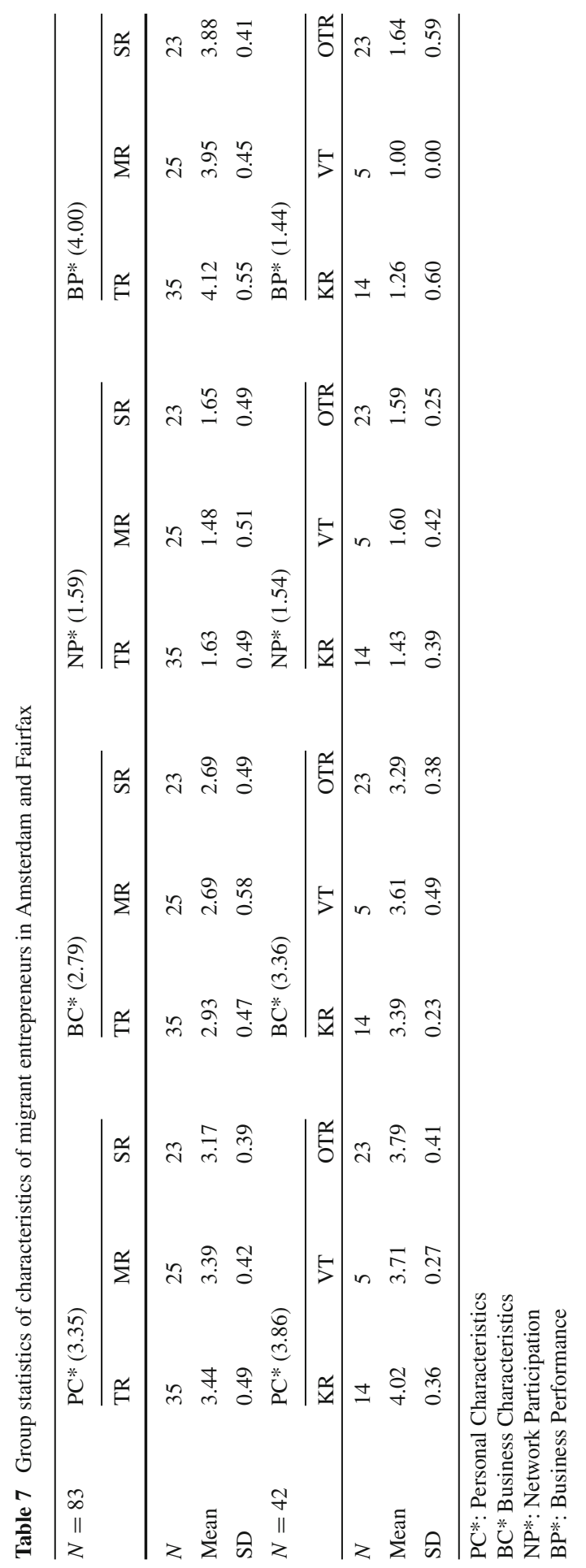


Table 8 Personal characteristics of migrant entrepreneurs (Amsterdam)

\begin{tabular}{|c|c|c|}
\hline & Number of entrepreneurs & Share in total (\%) \\
\hline \multicolumn{3}{|l|}{ Ethnic origin } \\
\hline Moroccan & 25 & 30 \\
\hline Surinamese & 23 & 28 \\
\hline Turkish & 35 & 42 \\
\hline \multicolumn{3}{|l|}{ Age } \\
\hline $20-25$ & 11 & 13 \\
\hline $26-30$ & 24 & 29 \\
\hline $31-35$ & 20 & 24 \\
\hline $36-40$ & 15 & 18 \\
\hline $41-$ & 13 & 16 \\
\hline \multicolumn{3}{|l|}{ Gender } \\
\hline Female & 15 & 18 \\
\hline Male & 68 & 82 \\
\hline \multicolumn{3}{|l|}{ Education level } \\
\hline Secondary school level & 11 & 13 \\
\hline Middle vocational training & 12 & 14 \\
\hline Higher vocational training & 30 & 37 \\
\hline University & 26 & 31 \\
\hline Other & 4 & 5 \\
\hline \multicolumn{3}{|l|}{ Marital status } \\
\hline Unmarried & 36 & 43 \\
\hline Married & 39 & 47 \\
\hline Divorced & 7 & 9 \\
\hline Unknown & 1 & 1 \\
\hline \multicolumn{3}{|l|}{ Family status } \\
\hline With children & 42 & 51 \\
\hline Without children & 41 & 49 \\
\hline Total & 83 & 100 \\
\hline
\end{tabular}

from different ethnic origin are mostly males (82\%). The Pearson Chi-Square rate in this case amounts to 0.956 (see Table 8), which indicates that there is no significant difference between the three groups investigated. Furthermore, we find that $37 \%$ of the respondents (of the total sample) have a high vocational education level. At the university level, $31 \%$ of the approached migrant entrepreneurs have a university-level diploma. This means that, altogether, most respondents have a high education level of schooling. When comparing the level of education for the three groups, in particular, we find that in all groups most of the respondents have a high level of vocational education. For example, among the Turkish entrepreneurs $13.3 \%$ of the respondents have a high vocational education level, while these figures are $15 \%$ for the Moroccan entrepreneurs and $8 \%$ for the Surinamese entrepreneurs. However, if we only examine the university education level, we find that most of the respondents of Surinamese 
Table 9 Entrepreneurial characteristics of migrant entrepreneurs (Amsterdam)

\begin{tabular}{lllll}
\hline & \multicolumn{2}{l}{ Number of entrepreneurs } & \multicolumn{2}{l}{ Share in total $(\%)$} \\
\hline Entrepreneurs in family & Yes & No & Yes & No \\
Total sample & 25 & 58 & 30 & 70 \\
Entrepreneurs in family by ethnic group & & & \\
$\quad 4$ & 21 & 16 & 84 \\
$\quad$ Moroccans & 8 & 15 & 35 & 65 \\
$\quad$ Surinamese & 13 & 22 & 37 & 63 \\
$\quad$ Turkish & 31 & 52 & & \\
Network participation & 13 & 12 & 37 & 63 \\
$\quad$ Total sample & 7 & 16 & & \\
Network participation of migrant entrepreneurs by ethnic group & 52 & 48 \\
$\quad$ Moroccans & 11 & 24 & 30 & 70 \\
$\quad$ Surinamese & 83 & & 31 & 69 \\
$\quad$ Turkish & & 100 & \\
Total & & & &
\end{tabular}

Table 10 Pearson chi-square values of sample of Dutch migrant entrepreneurs

\begin{tabular}{|c|c|c|}
\hline \multirow{8}{*}{$\begin{array}{l}\text { Table } 10 \text { Pearson chi-square } \\
\text { values of sample of Dutch } \\
\text { migrant entrepreneurs }\end{array}$} & Variables & Pearson chi-square \\
\hline & Age & $0.04^{*}$ \\
\hline & Gender & 0.956 \\
\hline & Birthplace & $0.0001^{*}$ \\
\hline & Education & 1.22 \\
\hline & Marital status & $0.024^{*}$ \\
\hline & Children & $0.038^{*}$ \\
\hline & Entrepreneur in family & 0.18 \\
\hline 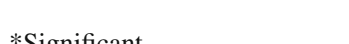 & Network participation & 0.4 \\
\hline
\end{tabular}

*Significant

origin went to the University and have the highest level of education. The Pearson Chi-Square rate in this case appears to be 0.122 (see Table 10). We may thus conclude that overall the migrant entrepreneurs do not differ significantly from each other in regard to their education level.

Twenty-six entrepreneurs of Turkish origin were born in Turkey, 13 of the entrepreneurs of Moroccan origin were born in Morocco and as for the Surinamese entrepreneurs, 12 persons were born in Surinam. The Pearson Chi-Square statistic in this case is 0.0001 (see Table 10), which indicates that there is a significant difference between the groups in terms of their birth place. Furthermore, a comparison was made between the sample groups regarding their marital status and children. From Table 8, we can conclude that most respondents were married and have one child. Most of the Moroccan and Surinamese entrepreneurs were unmarried, viz. 16 and 18\%, respectively. The Pearson Chi-Square rate in this case amounts 0.024 (see Table 10), which indicates that there is a significant difference between the groups regarding their marital status. Most of the Turkish entrepreneurs have 2 children, while most Moroccan 
and Surinamese entrepreneurs do not have children. The Pearson Chi-Square rate in this case is 0.038 (see Table 10), which indicates that there is a significant difference between the groups.

Table 9 shows entrepreneurs in the family by ethnic group. We can see that 58 respondents of different ethnic origin do not have an entrepreneur in the family (70\%). This is $22(26 \%)$ among Turkish entrepreneurs, while being 21 (25\%) among Moroccan entrepreneurs and 15 (18\%) among Surinamese entrepreneurs, respectively. Only $25(30 \%)$ entrepreneurs of different ethnic origin do have an entrepreneur in the family. This is 13 (Turkish entrepreneurs), 4 (Moroccan entrepreneurs) and 8 (Surinamese entrepreneurs), respectively. The Pearson Chi-Square rate amounts to 0.18 (see Table 10), which indicates that there is no significant difference between the groups.

Finally, we investigated the participation level in formal business networks (see Table 9). Most of the Turkish and Surinamese entrepreneurs did not participate in such networks. On the other hand, 13 of the 25 Moroccan entrepreneurs do participate in such networks. The Pearson Chi-Square rate amounts to 0.4 (see Table 10), which indicates that there is no significant difference between the groups in case of formal business network participation.

Trust in migrant networks is a subject worth examining further. For example: why is the participation rate for migrant entrepreneurs relatively low with regard to formal networks such as franchise organizations? Whereas such organizations play an important role for native entrepreneurs, migrant entrepreneurs usually do not participate in this. It can be that 'trust' plays a role in this issue, but this is for the time being speculative. We can nevertheless explain the migrant dependency by trust. Clients from the own migrant group play a major role for migrant entrepreneurs. It is possible to reverse this notion and ask ourselves the question: 'Why do migrant customers prefer a service from the migrant entrepreneur?' The cause may be in the fact that both share the same language, culture and religion and therefore communicate better. This brings a closer bonding to each other, through which the aspect of 'trust' can be understood. Hereby also the migrant entrepreneur can satisfy special needs of these types of customers, since they have a better knowledge than their native peers about specific products, which are appreciated by migrant customers.

Table 10 presents an overview of the profile of the respondents and the Pearson Chi-Square ( $p$ value) of the statistical difference. The Pearson Chi-Square is used here in order to find out whether there is a statistically significant difference between the selected migrant groups. We use a reliability level of $95 \%$, which indicates that there is a significant difference when the outcome is below a probability of 0.05 . The groups differ only significantly from each other in terms of their age, birthplace, marital status and children. The corresponding $p$ values of these variables are contained in Table 10.

4.2 Database on migrant entrepreneurs in the service and retail sectors in Fairfax county

Next, we present the profile of ethnic entrepreneurs in Fairfax County. Fairfax County is a county in Northern Virginia, in the US. The estimated population is 1,177,000. A county is a local level of government smaller than a state, that often either contains 
Table 11 Personal characteristics of migrant entrepreneurs (Fairfax)

\begin{tabular}{|c|c|c|}
\hline & $\begin{array}{l}\text { Number of } \\
\text { entrepreneurs }\end{array}$ & $\begin{array}{l}\text { Share in } \\
\text { total }(\%)\end{array}$ \\
\hline \multicolumn{3}{|l|}{ Ethnic origin } \\
\hline Korean & 14 & 33 \\
\hline Vietnamese & 5 & 12 \\
\hline Other & 23 & 55 \\
\hline \multicolumn{3}{|l|}{ Age } \\
\hline $21-30$ & 5 & 12 \\
\hline $31-40$ & 12 & 29 \\
\hline $41-50$ & 9 & 45 \\
\hline$>51$ & 6 & 14 \\
\hline \multicolumn{3}{|l|}{ Gender } \\
\hline Female & 20 & 48 \\
\hline Male & 22 & 52 \\
\hline \multicolumn{3}{|l|}{ Education level } \\
\hline Secondary & 4 & 10 \\
\hline Vocational training & 12 & 28 \\
\hline University & 26 & 62 \\
\hline \multicolumn{3}{|l|}{ Marital status } \\
\hline Unmarried & 7 & 17 \\
\hline Married & 33 & 78 \\
\hline Divorced & 2 & 5 \\
\hline \multicolumn{3}{|l|}{ Family status } \\
\hline With children & 33 & 79 \\
\hline Without children & 9 & 21 \\
\hline Total & 42 & 100 \\
\hline
\end{tabular}

a city or town and in some cases is an element of a large metropolitan region. In many states, counties are subdivided into townships or towns and may contain other independent municipalities. Fairfax County, which is part of the U.S. National Capital City region, is home to a wide diverse population from different ethnic origin with a significant number of Korean-Americans, Vietnamese-Americans, Indian-Americans, Jewish-Americans, and Pakistani-Americans and persons of Hispanic origin. According to the census of 2000, there were $73 \%$ Whites, $9 \%$ African Americans, $0.5 \%$ Native Americans, $13 \%$ Asians, $11 \%$ Hispanics or Latinos and 10\% of other races. Table 11 shows that most entrepreneurs in Fairfax county are males aged between 41 and 50 years $(57 \%)$ and that $57 \%$ of the respondents have a university education; $57 \%$ were born in Korea, 24\% in Vietnam and $19 \%$ in other countries.

Further, a comparison was made between the sample groups regarding their marital status and children. From Table 11, we can conclude that most respondents were married and have children. The corresponding Pearson Chi-Square rates in Table 13, indicate that there is a significant difference between the groups in terms of their birthplace, education, marital status and children. The Pearson Chi-Square outcomes are below a $p$ value of 0.05 . 
Table 12 Entrepreneurial characteristics of migrant entrepreneurs in Fairfax County

\begin{tabular}{lllll}
\hline & \multicolumn{2}{l}{ Number of entrepreneurs } & \multicolumn{2}{l}{ Share in total (\%) } \\
\hline Entrepreneurs in family & Yes & No & Yes & No \\
Total sample & 29 & 13 & 69 & 31 \\
Entrepreneurs in family by ethnic group & & & \\
$\quad$ Korean & 9 & 5 & 64 & 36 \\
$\quad$ Vietnamese & 4 & 1 & 80 & 20 \\
$\quad$ Other & 16 & 7 & 70 & 30 \\
Network participation & & & & \\
$\quad$ Total sample & 26 & 16 & 64 & 36 \\
Network participation of migrant entrepreneurs by ethnic group & & \\
$\quad$ Korean & 11 & 3 & 79 & 21 \\
$\quad$ Vietnamese & 3 & 2 & 60 & 40 \\
$\quad$ Other & 12 & 11 & 52 & 48 \\
Total & 42 & & 100 & \\
\hline
\end{tabular}

Table 13 Pearson chi-square values of sample of migrant entrepreneurs in Fairfax

\begin{tabular}{ll}
\hline Variables & Pearson chi-square \\
\hline Age & 0.08 \\
Gender & 0.758 \\
Birthplace & $0.003^{*}$ \\
Education & $0.0001^{*}$ \\
Marital status & $0.0001^{*}$ \\
Children & $0.0001^{*}$ \\
Entrepreneur in family & 0.123 \\
Network participation & 0.14 \\
\hline
\end{tabular}

*Significant

Table 12 shows entrepreneurs in the family by ethnic group in Fairfax; $69 \%$ of the respondents have an entrepreneur in the family: 58\% Korean, 80\% Vietnamese and $50 \%$ other, respectively. Most of the entrepreneurs in Fairfax appear to participate in formal business networks. The Pearson Chi-Square rate in this case amounts to 0.4 (see Table 13), which indicates that there is no significant difference between the groups in case of formal business network participation.

The corresponding $p$ values of the aforementioned variables are contained in Table 13 . We used a reliability level of $95 \%$, which indicates that there is a significant difference when the outcome is below a $p$ value of 0.05 .

\section{Data envelopment analysis as an assessment tool for business efficiency}

In the industrial organization literature of the past decades, a great deal of attention has been paid to the evaluation of efficiency differences among decision-making units (DMUs) involved in multi-product and multi-input activities. Data envelopment analysis (DEA) is an operational and quantitative, non-parametric method in production 
efficiency analysis that is generally used to judge the efficiency of firms or non-profit organizations. There are several different explanatory and multidimensional analyses and models to investigate the efficiency contribution of variables. A prominent class of approaches is found by multiple regression models. ${ }^{2}$ In our case, we use DEA, because our study only aims to address the efficiency of individual entrepreneurs. The general idea is that the production process of a DMU can be described by a generalized production function which may contain multiple input and multiple output factors. The most efficient production technology of such a composite production process can be described by means of the production possibility frontier, while the actual position of a firm-in terms of its realized efficiency or relative use of input factors to achieve a certain output (or a set of outputs)—can be represented by a point in either the input space or the output space.

DEA is based on the seminal work of Farrell (1957), later on extended by Charnes et al. (1978) and Banker et al. (1984). This method has been applied numerous times to operational efficiency problems in public-sector agencies (schools, airports, hospitals, etc.) as well as in private-sector agencies (banks, hotels, airlines, etc.). A major advantage of DEA is that it does not require any a priori specified functional form of the production technology, since it is - in contrast to traditional production theorygenerated from empirical data on observed performance measures (both inputs and outputs). In general, DEA models assess the (in) efficiency of a DMU on the basis of the actual economic distance to the production frontier that gives the highest possible efficiency. The efficiency analysis developed by Charnes et al. (1978) aims to maximize production efficiency in terms of the ratio of total weighted output to total weighted input, subject to the condition that in all circumstances this efficiency measure is smaller than or equal to 1 . Thus, the distance to the maximum value 1 is then seen as a measure of inefficiency.

A standard approach in DEA is the estimation of weights, which are calculated in a standard way by specifying a multiple objective maximization model (in case of multiple outputs). In that case the weights are determined through a maximization exercise faced by each DMU. The following steps are normally undertaken (see also Cracolici and Nijkamp 2006; Suzuki et al. 2007):

- Specification of a fractional maximization problem by each DMU (in terms of ratios of weighted outputs to weighted inputs) with the aim to identify the optimal weights.

- Transformation of the above nonlinear maximization problem into a standard linear programming problem in order to compute the input and output weights. This primal linear programming model represents an output-oriented approach, while its dual formulation indicates an input orientation (for a given level of outputs, inputs are minimized).

- If the solution to the maximization problem leads to a value 1 for some DMU, then this DMU is efficient (i.e., a case of a non-dominated solution), while a value

\footnotetext{
2 An interesting application using a Partial Least Squares (PLS) model can be found in Lejpras and Stephan (2009) in this issue.
} 


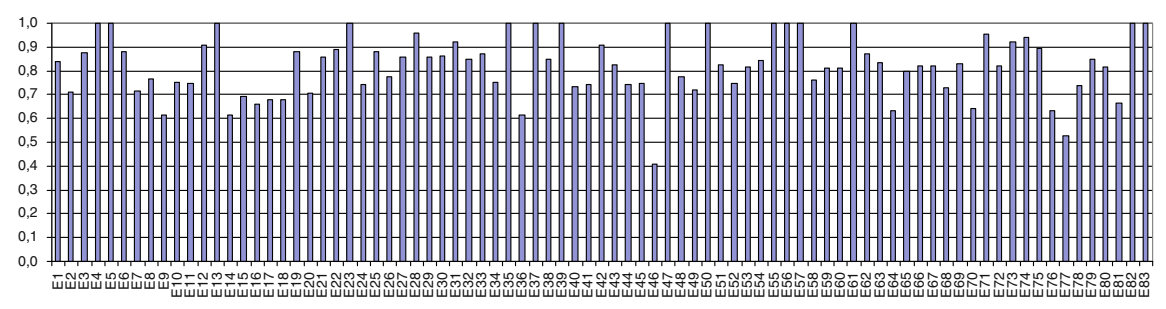

Fig. 2 Efficiency score of individual migrant entrepreneurs in Amsterdam

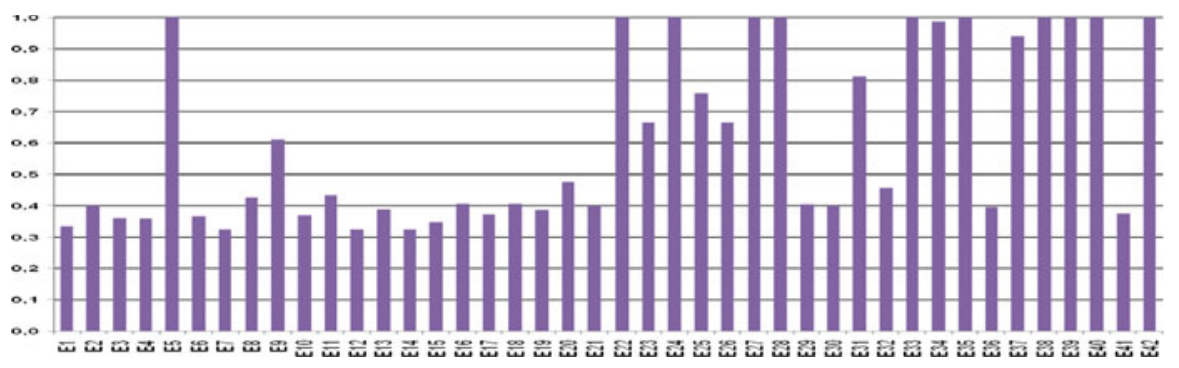

Fig. 3 Efficiency score of individual migrant entrepreneurs in Fairfax

below 1 indicates a case of inefficiency. Clearly, all points on the efficiency frontier have a value of 1 .

- If one or more inputs or outputs are added to the DEA method, this will affect the selection and the number of effectively operating DMUs. In general, if more relevant inputs are added, the number of efficient DMUs will rise. Thus, this is a clear reason to pay attention to the specification of the DEA model, while a sensitivity analysis regarding the choice of the inputs or outputs is also desirable.

The previous steps will also be used in our empirical analysis of the performance of migrant entrepreneurs in Amsterdam.

\subsection{DEA Results for migrant entrepreneurs in Amsterdam and Fairfax}

We will now analyse the economic performance of our samples of migrant entrepreneurs. In our empirical assessment we use Data Envelopment Analysis (DEA) to judge the efficiency or performance level of the firms in our sample, for both Amsterdam and Fairfax. DEA has become an established quantitative research tool in efficiency analysis in corporate and other organizations (see Charnes et al. 1978; Nijkamp et al. 2008). DEA offers a measure of the relative efficiency of each decision-making unit or agent considered, using the highest-performing agent as a benchmark.

The DEA approach was conducted for each of the two samples: 83 migrant entrepreneurs in Amsterdam and 42 migrant entrepreneurs in Fairfax (the results are given in Figs. 2 and 3).

Figure 2 shows that 15 of the 83 entrepreneurs in the Amsterdam sample are efficient (they have relative efficiency scores of 1.00, which is maximum possible score). Next, 
a subdivision of the three migrant categories was carried out, and a DEA analysis was applied to each of the three migrant categories separately in our sample, viz. Turks, Moroccans and Surinamese. The results are contained in Fig. 4, which shows the efficiency scores of the entrepreneurs categorized by ethnic origin. 7 entrepreneurs of Turkish origin, 12 entrepreneurs of Moroccan origin and 5 entrepreneurs of Surinamese origin are efficient in their own group. Furthermore, it is interesting to see that, in particular, the number of efficient entrepreneurs of Moroccan origin has doubled in this second efficiency analysis categorized by ethnic origin, compared with the first analysis of the 83 entrepreneurs. In their own circle, Moroccan enterprises, according to the DEA analysis, perform well, but if we take the three groups together, the Moroccans perform less well compared to the broader reference group of all companies. Figure 3 shows that 12 of the 42 entrepreneurs in the Fairfax sample are efficient (they have relative efficiency scores of 1.00, which is maximum possible score).

The results of the subdivision of the three migrant categories and the DEA analysis in the Fairfax sample are contained in Fig. 5. This figure shows the efficiency scores of the entrepreneurs categorized by ethnic origin. 10 entrepreneurs of other origin than Korean and Vietnamese, and one Korean entrepreneur are efficient in their own group.

\section{Conclusions}

It is noteworthy that the past decades have shown remarkable growth in entrepreneurship among migrants. Recent studies on ethnic entrepreneurship have observed an increasing share of migrants in urban small- and medium-sized entrepreneurial businesses. The phenomenon of migrant entrepreneurship deserves more in-depth scientific investigation, on the basis of, inter alia, comparative studies in terms of incubator conditions and critical success factors (CSFs) for a promising and efficient business performance. Given the growing importance of entrepreneurship, there is practical value in being able to identify CSFs. Due insight into entrepreneurial behaviour and the relative performance of migrants is needed in developing an effective business policy in which migrants are seen as a source of new socio-economic opportunities, for both the migrant groups and the city concerned. Strategic information will also be necessary for the development of fine-tuned policy strategies for enhancing the participation of traditionally less-privileged groups and for improving their business performance potential.

This paper next addresses in particular ethnic entrepreneurship as a major force field in the SME sector in many contemporary urban areas. The social and human capital factors involved are given due attention. This is followed by two empirical studies - one from the Netherlands and one from the US—which are presented to highlight the impact of social and human capital on business performance. Research studies on motivation and critical success conditions for ethnic entrepreneurs demonstrate that performance conditions vary across ethnic groups. The studies that consider differences by race and ethnicity find that human capital, access to finance and industry structures may produce systematic differences (Bates 1993; Fairlie 1999; Butler and Greene 1997). 


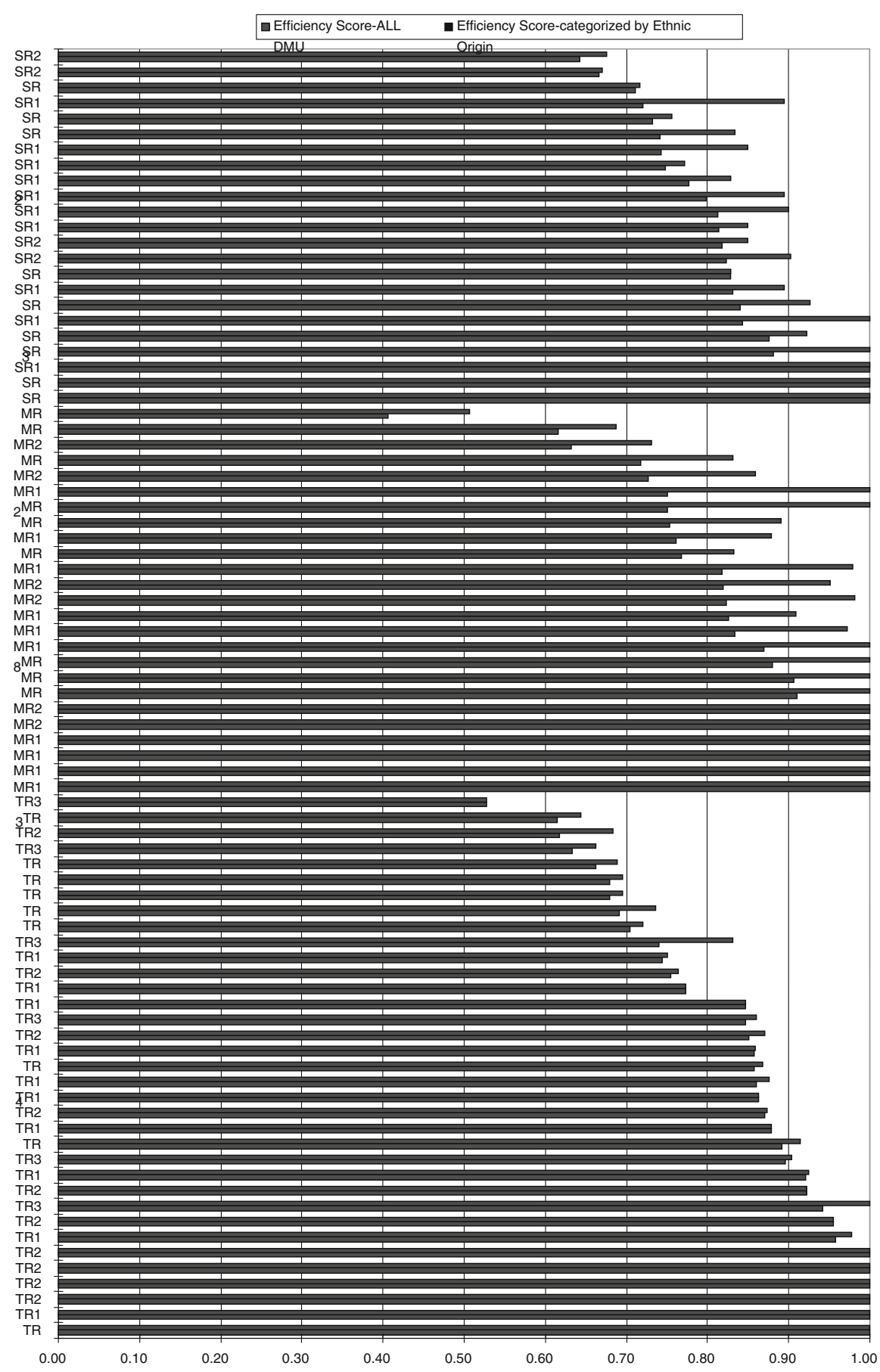

Fig. 4 Efficiency score of entrepreneurs categorized by ethnic origin (Amsterdam). SR Surinamese, $M R$ Moroccan, $T R$ Turkish 


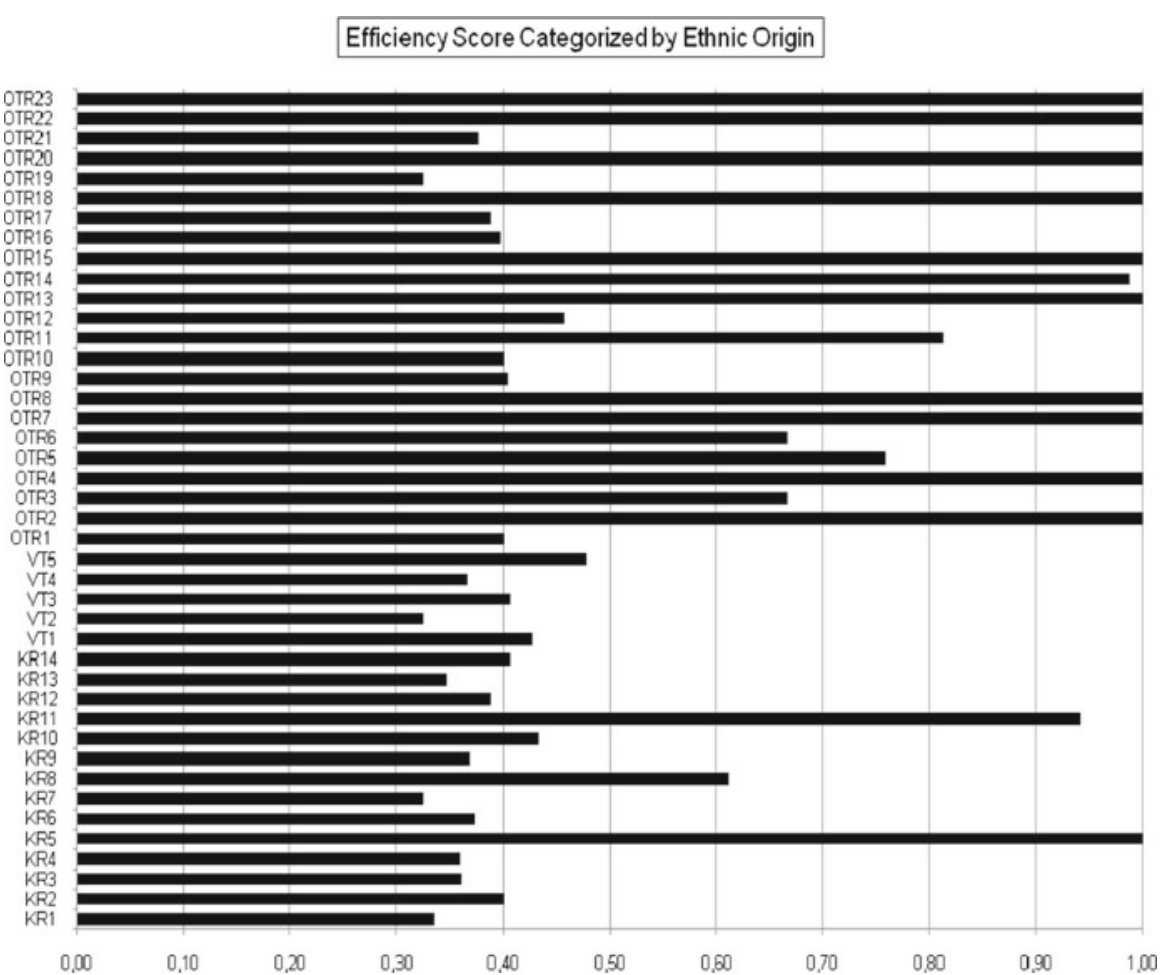

Fig. 5 Efficiency score of entrepreneurs categorized by ethnic origin (Fairfax). OTR Other origin, VT Vietnamese, KR Korean

Minority-owned businesses lag behind non-minority-owned businesses in terms of sales, profits, survivability and employment; facing greater obstacles in obtaining financing for their business implies that an already difficult situation is growing worse. According to Holguin et al. (2006), there are several significant barriers that specifically are faced by some groups of ethnic entrepreneurs in the US. Access to financial capital, access to mentors and networks, access to labor pads and barriers to marketplace are highly important to start a business and can discourage the development of the business. Studies of migrant and ethnic communities, in particular, show that minority businesses that are better embedded in the local community serve a large share of area residents, and help their community as a whole do better than they might have otherwise.

The results of our analysis, based on DEA analysis, show that the performance of migrant entrepreneurs may differ based on their efficiency rate. The above findings are certainly provisional and call for more solid research on a large sample of migrant entrepreneurs. For further research it will be interesting to examine possible reasons for differences in performance and efficiency rates between migrant entrepreneurs. Possible reasons for low, or differences in, efficiency rates amongst migrant entrepreneurs may be caused by the limited potential for growth of their market niches, because several of these entrepreneurs appear to operate in limited markets. 
Other reasons for their low-efficiency rate may be less labour (-market) experience and lack of entrepreneurial experience.

For further research it will be also interesting to compute the proportion of space filled by the bars of the graphs in Figs. 4 and 5 to the total space and to create a ratio of group-specific efficiency. Alternatively, it is possible to create a slope measure that is computed across the bars of each sub-graph. The steeper the slope the more efficient the group. Such measures could be used to compare relative group efficiencies. Such follow-up research could offer a new contribution to the literature on the DEA methodology and comparative efficiency analysis too.

Finally, we need some more analysis in order to make some conclusions. First, by using a group measure of efficiency as described earlier it is possible to create a new measure for group efficiency and to identify the importance of this for making inter-group comparisons. Second, running a regression analysis with as the dependent variable the efficiency score and as independent variables business inputs (both aggregate and for Amsterdam and Fairfax separately, and for the specific groups of entrepreneurs) to determine which independent variables are more important and how much consistency there is across groups is a relevant item for further research.

Open Access This article is distributed under the terms of the Creative Commons Attribution Noncommercial License which permits any noncommercial use, distribution, and reproduction in any medium, provided the original author(s) and source are credited.

\section{References}

Acs ZJ, Armington C (eds) (2006) Entrepreneurship, geography, and American economic growth. Cambridge University Press, Cambridge

Acs ZJ, Audretsch DB (eds) (1993) Small firms and entrepreneurship; an east-west perspective. Cambridge University Press, Cambridge

Adler PS, Kwon SW (2002) Social capital: prospects for a new concept. Acad Manag Rev 27(1):17-40

Aldrich HE, Zimmer C (1986) Entrepreneurship through social networks. In: Sexton DL, Wilson RW (eds) The art and science of entrepreneurship. Ballinger, Cambridge, pp 154-167

Anderson AR, Miller CJ (2003) Class matters: human and social capital in the entrepreneurial process. J Socio Econ 32(1):17-36

Aronson D (1997) Research perspectives on migration. A joint project of the International Migration Policy Program of the Carnegie Endowment for International Peace and the Urban Institute 1(2)

Audretsch DB, Thurik AR (2001) What's new about the new economy? Sources of growth in the managed and entrepreneurial economies. Ind Corp Change 1(10):267-315

Banker RD, Charnes A, Cooper WW (1984) Some models for estimating technical and scale inefficiencies in data envelopment analysis. Manag Sci 30:1078-1092

Basu A (1998) An exploration of entrepreneurial activity among Asian small businesses in Britain. Small Bus Econ 10:313-326

Bates T (1993) Assessment of state and local government minority business development programs. US Department of Commerce, Washington, DC

Bates T (1994a) An analysis of Korean-immigrant-owned-small-business start-ups with comparisons to African-American-and nonminority-owned firms. Urban Aff Q 30(2)

Bates T (1994b) Social resources generated by group support networks may not be beneficial to Asian immigrant-owned small businesses. Soc Forces 72(3):671-689

Bates T (1999) Race, self-employment, and upward mobility: an illusive American dream; response to John Sibley Butler's review essay. Small Business Economics, vol 12, pp 189-190. Springer

Baum RJ, Locke EA, Smith KG (2001) A multidimentional model of venture growth. Acad Manag J 44(2):292-303 
Baycan-Levent T, Masurel E, Nijkamp P (2003) Diversity in entrepreneurship: ethnic and female roles in urban economic life. Int J Soc Econ 30(11):1131-1161

Becker GS (1975) Human capital—a theoretical and empirical analysis with special reference to education. The Press of Chicago University, Chicago

Birley S, Ghaie S (1992) Networking by the Indian community in Northern Ireland, Working Paper. Imperial College, London

Bonacich E, Light I, Wong C (1976) Small business among Koreans in Los Angeles. In: Gee E (ed) Counterpoint: perspectives on Asian America. Asian American Studies Center, Los Angeles

Borjas G (1990) Friends or strangers: the impact of immigrants on the US economy. Basic Books, NewYork

Boubakri H (1999) Les Entrepreneurs Migrants d'Europe. Paris: Culture \& Conflits, Sociologie Politique de l'International, Printemps-Été, Paris

Bourdieu P (1986) The forms of capital. In: Richardson JG (ed) Handbook for theory and research for the sociology of education. Greenwood, New York, pp 241-258

Brown TC, Hanlon D (2004) Validation of key behaviours for effective entrepreneurship. Paper presented at the BKERC, Glasgow, 3-5 June

Brücker H, Epstein GS, McCormick B, Saint-Paul G, Venturini A, Zimmermann KF (2002) Managing migration in the European welfare state. In: Boeri T, Hanson G, McCormick B (eds) Immigration policy and the welfare system. Oxford University Press, Oxford, pp 1-168

Butler JS, Greene PG (1997) Ethnic entrepreneurship: the continuous rebirth of American entrepreneurship. In: Sexton DL, Smilor RW (eds) Entrepreneurship 2000. Upstart Publishing, Chicago, pp 267-289

Carland J, Carland JC (1993) The role of personality in new venture creation. Entrepreneur Innov Change 2(2):129-140

CEEDR (2000) Young entrepreneurs, women entrepreneurs, ethnic minority entrepreneurs and co-entrepreneurs in the European Union and Central and Eastern Europe. Final Report to the European Commission, DG Enterprise, Centre for Enterprise and Economic Development Research (CEEDR) Middlesex University Business School, UK

Charnes A, Cooper WW, Rhodes E (1978) Measuring the efficiency of decision making units. Eur J Oper Res 2:429-444

Choenni A (1997) Veelsoortig Assortiment. Het Spinhuis, Amsterdam

Chou YK (2006) Three simple models of social capital and economic growth. J Soc Econ 35(5):889-912

Cooper A, Gimeno-Gascon J, Woo C (1994) Initial human and financial capital as Predictors of new ventures performance. J Bus Ventur 9:371-395

Cracolici MF, Nijkamp P (2006) Competition among tourist destinations. In: Giaoutzi M, Nijkamp P (eds) Tourism and regional development. Ashgate, Aldershot, pp 133-152

Dagevos J, Gesthuizen M (2005) Niet-westerse Allochtonen met een Stabiele Arbeidsmarktpositie: Aantallen en Ontwikkelingen. Sociaal en Cultureel Planbureau, Den Haag

Dasgupta P, Serageldin I (eds) (1999) Social capital. A multifaceted perspective. The World Bank, Washington, DC

De Carolis D, Saparito P (2006) Social capital, cognition and entrepreneurial opportunities: a theoretical framework. Entrepreneur Theory Pract 30(1):41-56

Deakins D, Majunder M, Paddison A (1997) Developing success strategies for ethnic minorities in business: evidence from Scotland. New Commun 23:325-342

Delft H, van Gorter C, Nijkamp P (2000) In search of ethnic entrepreneurship in the city. Environ Planning C 18:429-451

Dhaliwal S (1998) Silent contributors: Asian female entrepreneurs and women in business. Womens Stud Int Forum 21(5):463-474

Driessen M, Zwart P (2006) De E-scan Ondernemerstest ter Beoordeling van Ondernemerschap. MAB 80(7/8):382-391

Dyer LM, Ross CA (2000) Ethnic enterprises and their clientele. J Small Bus Manag 38(2):48-66

Evans MDR (1989) Immigrant entrepreneurship: effects of ethnic market size and isolated labor pool. Am Soc Rev 54:950-962

Fairlie RW (1999) The absence of the African-American owned business: an analysis of the dynamics of self-employment. J Labor Econ 17:80-108

Farrell MJ (1957) The measurement of productive efficiency. J R Stat Soc Ser A 120:253-281

Florin J, Lubatkin M, Schulze W (2003) A social capital model of high-growth ventures. Acad Manag J 46(3):374-384 
Fratoe F (1988) Social capital and black business owners. Rev Black Polit Econ 16(4):33-50

Fukuyama F (1995) Trust: social virtues and the creation of prosperity. Free Press, New York

Glaeser EL, Laibson DK, Scheinkman JA, Soutter CL (2000) Measuring trust. Q J Econ 115(3):811-846

Greenwood MJ (1994) Potential channels of immigrants influence on the economy of the receiving country. Pap Reg Sci 73:211-240

Hammarstedt M (2001) Immigrant self-employment in Sweden-its variation and some possible determinants. Entrepreneur Reg Dev 13:147-161

Hansemark O (1998) The effects of an entrepreneurship programme on need for achievement and locus of control of reinforcement. Int J Entrepreneur Behav Res 4(1):28-50

Hébert RF, Link AN (1989) In search of the meaning of entrepreneurship. Small Bus Econ 1:39-49

Hipple S (2004) Self-employment in the United States: an update. Mon Labor Rev 13:13

Ho TS, Koh HC (1992) Differences in psychological characteristics between entrepreneurially inclined and non-entrepreneurially inclined accounting graduates in Singapore. Entrepreneur Innov Change $1: 243-254$

Holguin J, Gamboa E, Hoy F (2006) Challenges and opportunities for hispanic entrepreneurs in the United States. In: Dana LP (ed) Migrant entrepreneurship. Edward Elgar, Aldershot, pp 99-113

Iyer GR, Shapiro JM (1999) Ethnic entrepreneurial and marketing systems: implications for the global economy. J Int Market 7(4):83-110

Jacobs J (1961) The life and death of great American cities. Random House, New York

Johnson BR (1990) Toward a multidimensional model of entrepreneurship: the case of achievement motivation and the entrepreneur. Entrepreneur Theory Pract, pp 39-54

Kakati M (2003) Success criteria in high-tech new firms. Technovation 23:447-457

Kalantardis C, Bika Z (2006) In-migrant entrepreneurship in rural England: beyond local embeddedness. Entrepreneur Reg Dev 18:109-131

Keeble D (1989) High technology industry and regional development in Britain: the case of the Cambridge phenomenon. Gov Policy 7:152-172

Keeble D, Tyler P (1995) Enterprising behaviour and the urban-rural shift. Urban Stud 32(6):975-997

Kim Ph.H, Aldrich HE, Keister LA (2003) Access (not) denied: the impact of financial, human and cultural capital on entrepreneurial entry in the United States. Small Bus Econ 27(1):5-22

Köllinger P, Minniti M (2006) Not for a lack of trying: American entrepreneurship in black and white. Small Bus Econ 27:59-79

Lee HS, Chang S (2005) Environmental jolts, internal buffers, and failures versus survivals of high-technology based ventures. Paper presented at BKERC, Boston, 8-11 June

Lee J, Lee S (2004) Failure factors of new technology-based ventures according to the growth stages, frontiers of entrepreneurship research. Babson College, Wellesley, pp 1-14

Lejpras A, Stephan A (2009) Locational conditions, cooperation, and innovativeness: evidence from research and company spin-offs. Ann Reg Sci (forthcoming)

Levie J (2007) Immigration, in-migration, ethnicity and entrepreneurship: insights from the GEM UK Database. Small Bus Econ 28(2):143-169

Levie J, Smallbone D (2006) Entrepreneurship, ethnicity and migration: current trends and future directions. In: Minniti M (ed) Perspectives on entrepreneurship, vol 1. Praeger, Westport, pp 157-180

Light I (1984) Immigrant and ethnic enterprise in North America. Ethn Racial Stud 7:195-216

Light I, Gold SJ (2000) Ethnic economies. Academic Press, San Diego

Light I, Roach E (1996) Self-employment: mobility ladder or economic lifeboat. In: Waldinger R, Bozorgmehr M (eds) Ethnic Los Angeles. Russell Sage Foundation, New York, pp 193-213

Light I, Rosenstein C (1995) Race, ethnicity and entrepreneurship in urban America. Aidine de Gruyter, New York

Lumpkin GT, Dess GG (1996) Clarifying the entrepreneurial orientation and linking it to performance. Acad Manag Rev 21:135-152

Marger M (1989) Business strategies among East-Indian entrepreneurs in Toronto: the role of group resources and opportunity structure. Ethn Racial Stud 12:539-563

Masurel E, Nijkamp P, Tastan M, Vindigni G (2002) Motivations and performance conditions for ethnic entrepreneurship. Growth Change 33(2):238-260

Menzies TV, Brenner GA, Filion LJ (2003) Social capital, networks and ethnic minority entrepreneurs: transnational entrepreneurship and bootstrap capitalism. In: Etemad H, Wright RW (eds) Globalization and entrepreneurship: policy and strategy perspectives. Edward Elgar, Northampton, pp 125-151 
Menzies TV, Doichon M, Gasse Y, Elgie S (2006) A longitudinal study of the characteristic, business creation process and outcome differences of Canadian female vs. male nascent entrepreneurs. Int Entrepreneur Manag J 2:441-453

Mesch GS, Czamanski D (1997) Occupational closure and immigrant entrepreneurship: Russian Jews in Israel. J Soc Econ 26:597-610

Min PG (1987) Factors contributing to ethnic business: a comprehensive synthesis. Int J Comp Sociol 28(3/4):173-193

Mueller P (2005) Exploring the knowledge filter-how entrepreneurship and university-industry relations drive economic growth. ERSA conference papers ersa05p610, European Regional Science Association

Nahapiet J, Ghoshal S (1998) Social capital, intellectual capital, and the organizational advantage. Acad Manag Rev 23(2):242-266

Nijkamp P (2003) Entrepreneurship in a modern network economy. Reg Stud 37(4):395-405

Nijkamp P, Sahin M, Suzuki S (2008) Migrant Entrepreneurs and the struggle for survival, a comparative study on the efficiency performance of migrant entrepreneurs in Amsterdam by means of data envelopment analysis. Reg Stud (forthcoming)

Oort FJ, van Atzema OALC (2004) On the conceptualization of agglomeration economics: the case of new firm formation in the Dutch ICT sector. Ann Reg Sci 38:263-290

Peterson MF, Roquebert J (1993) Success patterns of Cuban-American enterprises: implications for entrepreneurial communities. Hum Relat 46:921-935

Phizaklea A, Ram M (1996) Being your own boss: ethnic minority entrepreneurs in comparative perspective. Work, Employment and Society 10(2)

Portes A, Zhou M (1996) Self-employment and the earnings of immigrants. Am Sociol Rev 61(2):219-230

Prashantham S (2006) Foreign network relationships and the internationalization of small knowledge-intensive firms. Int J Entrepreneur Innov Manag 6(6):542-553

Putnam R (2000) Bowling alone: the collapse and revival of American community. Simon \& Schuster, New York

Ram M (1994) Managing to survive: working lives in small firms. Blackwell, Oxford

Richtmyer R (2002) KEMET building ties with Japan. US Dept of Commerce, Bureau of the Census

Robb A, Fairlie R (2007) Access to financial capital among U.S. businesses: the case of African American firms. Ann Am Acad Polit Soc Sci 613:4-72

Sahin M, Nijkamp P, Baycan-Levent T (2006) Is migrant entrepreneurship from the perspective of cultural diversity. In: Dana LP (ed) Migrant entrepreneurship. Edward Elgar, Aldershot, pp 99-113

Sahin M, Nijkamp P, Baycan-Levent T (2007) Migrant entrepreneurship from the perspective of cultural diversity. In: Aktan CC (ed) Advances in business and management. Cesme, Izmir, pp 103-121

Sanders J, Nee V (1996) Immigrant self employment: the family as social capital and the value of human capital. Am Sociol Rev 61:231-249

Shepherd DA, Douglas EJ, Shanley M (2000) New venture survival: ignorance, external shocks, and risk reduction strategies. J Bus Ventur 15:393-410

Shin E, Han S (1990) Korean immigrant small businesses in Chicago: an analysis of the resource mobilization process. Amerasia J 16(1):39-60

Sobel J (2002) Can we trust social capital?. J Econ Lit XL:139-154

Suzuki S, Nijkamp P, Rietveld P, Pels E (2007) Distance friction minimization approach in data envelopment analysis; an application to airport performance. Tinbergen Institute Discussion Paper TI 2009-024/3

Tanaka S, Krishnan A (2006) Migration-migrant entrepreneurship; cities, magnets of hope, habitat debate. World Habitat Day, 2 October 2006

Teder J, Golik M (2006) Ethnic minorities and entrepreneurship in Estonia. Paper presented at the 14th Nordic Conference on Small Business Research, Stockholm. http://www.ncsb2006.se/download_title. htm

Teixeira C (1998) Cultural resources and ethnic entrepreneurship: a case study of the Portuguese real estate industry in Toronto. Can Geogr 42(3):267-281

Tillie J, Slijper B (2006) Immigrant political integration and ethnic civic communities in Amsterdam. In: Benhabib S, Shapiro I (eds) Identities, allegiances and affiliations. Cambridge University Press, Cambridge

Torres DL (1988) Success and the Mexican-American business person. Res Sociol Organ 6:313-334

Velde MEG, van Jansen PGW, Telting IA (2000) Bedrijfswetenschappelijk Onderzoek: Van Probleemstelling tot Presentatie. Nelissen, Baarn 
Waldinger R (1988) The ethnic division of labour transformed: native minorities and new immigrants in post-industrial New York. New Community 14(3)

Waldinger R, Aldrich H, Ward R (eds) (1990) Entrepreneurs. Sage Publishers, Newbury Park

Walton-Roberts M, Hiebert D (1997) Immigration, entrepreneurship and the family: Indo-Canadian enterprise in the construction industry of greater vancouver. Can J Reg Sci 20(1-2):119-140

Ward R, Jenkins R (eds) (1984) Ethnic communities in business. Cambridge University Press, Cambridge

Wennekers S, Thurik AR (1999) Linking entrepreneurship and economic growth. Small Bus Econ 13(1):27-55

Werbner P (1999) What colour 'success'? Distorting value in studies of ethnic entrepreneurship. Sociol Rev 47(3):548-579

Westlund H, Bolton R (2003) Local social capital and entrepreneurship. Small Bus Econ 21:77-113

Westlund H, Nilsson E (2005) Measuring enterprises: investments in social capital. Reg Stud 39(8):1079_ 1094

Yu J, Stough RR (2006) The determinants of entrepreneurship and development in China. Int J Manag Entrepreneur Dev 3(1/2):30-52

Yuengert AM (1995) Testing hypotheses of immigrant self-employment. J Hum Res XXX(1)

Zorlu A, Traag T (2005) Opleidingsniveau en taalvaardigheid [Educational level and language proficiency]. Jaarrapport Integratie 2005, SCP/WODC/CBS, The Hague 